DOI: https://doi.org/10.18234/secuencia.v0i0.1708

Reseñas

\title{
Fotografía y memoria. Conversaciones con Eduardo Longoni
}

\author{
Luis Francisco Velarde Martínez @ https://orcid.org/0000-0001-8469-5054 \\ Doctorado en Historia \\ CIESAS-Peninsular, México \\ sabines47@hotmail.com
}

Alberto Del Castillo Troncoso, Fotografía y memoria. Conversaciones con Eduardo Longoni, Colombia, Fondo de Cultura Económica/CONACyT/Instituto Mora, 2017, 303 pp.

Con Fotografía y memoria, Alberto del Castillo suma un título más a su destacado trabajo de investigación en torno al uso de las imágenes para generar interpretaciones históricas y, particularmente, acerca del papel de los fotoperiodistas en la construcción de imaginarios sociales sobre procesos traumáticos producidos por la violencia de Estado en América Latina. (Anteriormente, ha realizado algunos trabajos sobre la fotografía del 68 en México).

En esta ocasión el autor se aproxima a la historia de Argentina, desde la última dictadura militar hasta la segunda década del siglo XXI, a través del itinerario profesional del fotógrafo y editor Eduardo Longoni. (El corte temporal sitúa al estudio en la perspectiva de la denominada historia del tiempo presente). El texto está estructurado a partir de una narrativa cronológica que alterna el relato en primera persona y el cruzamiento con otros testimonios orales con el análisis especializado del investigador y, por supuesto, el uso del documento fotográfico. Más que una biografía, en sentido estricto, el libro representa un ejercicio de análisis generacional muy próximo a la historia de la prensa escrita y, particularmente, del fotoperiodismo argentino de la segunda mitad del siglo XX.

Las etapas a través de las cuales se articula el trabajo son tres: el contexto histórico que parte de la dictadura del general Jorge Rafael Videla (1976-1981), el trayecto hacia la

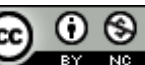
Internacional. 
transición y consolidación de la democracia, y el espacio temporal de la década de 1990 a principios de la siguiente. La trayectoria profesional de Longoni lo llevó desde la fotografía en la calle hacia la edición de diarios, revistas y libros, que incluyó el desarrollo mismo de la prensa escrita en aquel país, lo que permite apreciar en este texto cómo se entretejen la historia de vida, la formación del capital social del personaje y la historia cultural con énfasis en los procesos de producción y circulación de las imágenes.

La obra consta de ocho capítulos que se pueden agrupar en dos bloques: los primeros cuatro tratan sobre la postura política y la adscripción institucional del fotógrafo y editor, mientras que el resto centra su atención en sus trabajos y proyectos personales, cuyas características más notorias son el alto nivel del discurso fotográfico y el tratamiento, la calidad y profundidad de las imágenes. De acuerdo con la organización del libro, el primer apartado aborda el desempeño profesional de Longoni entre 1976 y 1983, periodo que atestigua su llegada a Noticias Argentinas (NA), su encuentro con Miguel Ángel Cuarterolo, a la larga junto con Henri Cartier-Bresson, una de sus más importantes influencias, sus primeras coberturas y la transformación de su compromiso social vinculado con el ejercicio profesional que a su entender implicaba: "empezar a tratar de mostrar con nuestras imágenes lo que ocurría en el país.” (p. 91).

Estos años estuvieron modelados tanto por un intenso activismo político que llevó al personaje a relacionarse con las Madres de la Plaza de Mayo y a cuestionar la cercanía de la iglesia católica con la dictadura y el papel de la policía y el ejército en la represión de los grupos opositores al régimen, como por las inquietudes e intereses propios de un joven que ha descubierto la vocación y pasión por su oficio. Así, durante esta etapa de su vida el periodista experimenta con su primer ensayo fotográfico sobre los comedores populares en Buenos Aires. 
De acuerdo con su testimonio, el periodo habría sido particularmente fértil para el establecimiento de redes profesionales (capital social) que insertaron al personaje en su gremio y lo involucraron en las exposiciones del periodismo gráfico argentino entre 1981 y 1983, muestras con un alto compromiso político y social. A través de la sociabilidad, el protagonista suple su carencia de formación escolar con la experiencia de la fotografía cotidiana y el trabajo colectivo con sus pares.

El segundo capítulo, por su parte, da cuenta de su paso como editor por Noticias Argentinas y la fundación de la Agencia EDP/Photo entre 1984-1990 durante la transición a la democracia. Esta fase estuvo marcada por tres acontecimientos relacionados con las Fuerzas Armadas: el juicio a las Juntas militares, la rebelión de los “carapintadas” y el ataque al cuartel de La Tablada. Longoni da puntual seguimiento a los tres casos y no sólo gestiona desde su encargo como editor de NA que se permita fotografiar el juicio a los miembros del ejército, sino que además guiándose por su olfato periodístico obtiene imágenes icónicas sobre tales sucesos, algunas de ellas, como las tomadas en el cuartel de La Tablada, incluso servirán posteriormente como prueba de la detención con vida de un grupo de rebeldes de los cuales no se volvió a tener noticia alguna.

Las secciones tres y cuatro del libro comprenden los periodos de 1990-2001 y 20012013, que corresponden con la estancia en el diario Clarín y la revista Viva, respectivamente. Este largo periodo se caracterizó por el despegue profesional de Longoni, quien pronto encontró retos y oportunidades en su nueva casa (para ese momento junto con La Nación, el Clarín era uno de los principales diarios del país), por ejemplo, se estrena como editor de libros. A nivel del desarrollo de la prensa, aquella época fue también de empoderamiento de la imagen, precedida por el cambio generacional en el equipo de trabajo dentro del periódico y sostenido por la inclusión de suplementos con alto contenido visual, así como por la transición de la fotografía analógica a la digital. 
En los ámbitos social y político aquellos años, ya en democracia, fueron convulsos y caóticos para la nación argentina y dos hechos lo confirman: el atentado terrorista contra la Asociación Mutual Israelita Argentina (AMIA) en Buenos Aires el 18 de julio de 1994, y la caída del presidente de la Rúa a finales de 2001, en medio de una violenta represión contra las protestas sociales en la calle. Por otro lado, los años en la revista Viva fueron también los de la inclinación de Longoni hacia proyectos más personales que tienden puentes con inquietudes vinculadas a las prácticas religiosas, como lo demuestra su trabajo sobre el culto a Cauchito Gil, un santo popular pagano de su país.

Finalmente, los capítulos cinco, seis, siete y ocho engloban cuatro proyectos editoriales que distinguen y en cierto sentido también distancian al fotógrafo de su trabajo previo, caracterizado hasta entonces por el compromiso de usar la fotografía para evidenciar amplios y complejos procesos sociales y políticos. Por el contrario, en sus últimos libros deja entrever algunos muy bien elaborados ensayos fotográficos, con imágenes bellas e impactantes.

Estos apartados describen el proceso de producción de una obra con Ernesto Sábato, dos con Mario Benedetti, una cuarta acerca de una constante en el trabajo fotográfico de Eduardo Longoni, titulado atinadamente "Violencias", y por último "Destiempos”, una “indagación acerca de las comunidades que viven como si el tiempo no trascurriera, como si se hubiera detenido” (p. 253), centrado en la orden de la iglesia católica conocida como los cartujos.

Desde una perspectiva historiográfica, el trabajo de Alberto del Castillo representa una valiosa contribución a la historia reciente de la nación argentina. El autor usa como eje de análisis la actividad profesional de Longoni para revisar la difícil transición hacia la democracia. De manera innovadora presenta el testimonio del fotoperiodista como si fuera él quien cuenta su historia. No hay preguntas, sólo el relato en primera persona, por tanto, Secuencia. E-ISSN 2395-8464 
el primer gran logro del historiador que no pasará desapercibido para quienes trabajan con testimonios orales, es organizar el material de las entrevistas para darle sentido y coherencia narrativa.

A partir de esa estructura inicial se derivan tres situaciones metodológicas, la revisión y el constante cuestionamiento del personaje sobre su propio pasado y la historia contemporánea de su país, el cruce de su testimonio con el de otros protagonistas de los hechos narrados en el libro y, en tercer lugar, la presencia del historiador que no sólo propicia este entrecruzamiento, sino que además inserta las imágenes del fotógrafo en el relato y desarrolla un análisis tanto de los aspectos técnicos como del sentido histórico de las mismas. Con ello "su mirada” de especialista y la de su interlocutor (la del fotógrafo) se conectan tal y como ocurre en una conversación cara a cara, de ahí lo acertado del subtítulo del libro: "Conversaciones con Eduardo Longoni”.

En el libro se incluyen 122 imágenes en su mayoría de Eduardo Longoni, pero también de otros colegas suyos. Además de los testimonios fotográficos, Del Castillo recurre a comunicaciones personales, fuentes hemerográficas y, desde luego, a una amplia bibliografía que sustenta lo mismo su aparato crítico que el contexto histórico de Argentina del periodo entre siglos. Respecto a la fotografía producida durante el corte temporal estudiado en el libro, el autor presta especial atención tanto a los contextos en los cuales se generó, como a los medios y las situaciones que posibilitaron o impidieron su difusión, ya fuera por razones personales o por la censura institucional.

Mención aparte merece el estudio de la significación social de las imágenes, que a nuestro entender se constituye a partir de la triada: producción-circulación-apropiación. Este ejercicio es tal vez el ejemplo máximo de diálogo entre el historiador y su personaje. Producto del trabajo en equipo donde Longoni cuenta cómo surgió la fotografía (contexto, 
condiciones técnicas), del Castillo desde su posición privilegiada, es decir, desde afuera del relato, analiza cómo estas imágenes se convirtieron en icónicas de la resistencia civil ante el terrorismo de Estado. A veces es el propio fotógrafo, seguramente inducido por las preguntas de su interlocutor, quien da las pistas iniciales, como cuando refiere sobre las madres de la Plaza de Mayo lo siguiente: “Algunos episodios se han convertido en íconos de la lucha de las madres. Creo que la foto más conocida es la de los caballos, que ganó un premio importante en Moscú en aquel momento.” (pp. 98-100).

De manera general, la obra se inserta en los estudios de la memoria vinculados al terrorismo de Estado en América Latina y a los realizados en el contexto argentino sobre el aporte de los fotoperiodistas a la democratización del sistema político. Esta línea está muy próxima a lo que el autor ha trabajado con la construcción del imaginario fotográfico sobre el 68 mexicano, a través del periódico El Heraldo de México o por medio del lente del periodista Rodrigo Moya. Sostiene Del Castillo: "los profesionales del lente no sólo registraron los hechos, sino que además resultaron ser uno de los factores que contribuyeron a hacer posible la transición democrática en Argentina.” (p. 17).

Más allá de todo lo anterior, Fotografía y memoria apela a lo más subjetivo y profundo del ser: el amor, el dolor, el horror, la soledad, la solidaridad humana, etcétera. Al mismo tiempo, el libro narra la historia de un hombre y su pasión infinita por la imagen, un profesionista que aprendió desde muy joven a mirar la vida a través del lente de su equipo, que usó su formación trunca en Historia para analizar el contexto político y social de su época y su sensibilidad e instinto para crear productos que, sin renunciar a la necesidad y el compromiso de evidenciar la realidad por muy dolorosa que esta sea, captaron también la belleza de lo simple y el misterio de lo complejo, es decir, lo humano. 